www.jmscr.igmpublication.org

Impact Factor (SJIF): 6.379

Index Copernicus Value: 71.58

ISSN (e)-2347-176x ISSN (p) 2455-0450

crossref DOI:_https://dx.doi.org/10.18535/jmscr/v6i2.41

Journal Of Medical Science And Clinical Research

IGM Publication

An Official Publication of IGM Publication

\title{
A Prospective Observational Study to Analyze the Causes and Types of Presenile Cataract in Subhimalayn Area of West Bengal
}

\author{
Authors \\ Dr Malabika Debbarma ${ }^{1}$, Dr Rupanjli Lakra ${ }^{2}$ \\ ${ }^{1,2}$ Assistant Professor, Department of Ophthalmology, North Bengal Medical College \& Hospital, \\ Sushruta Nagar, West Bengal, INDIA - 734012 \\ Corresponding Author \\ Dr Malabika Debbarma \\ Email: drmalabika@gmail.com, Mobile: 9434071991
}

\begin{abstract}
Presenile is the development of cataract before the age of 50 years. Cataract is the opacification of the crystalline lens and or its capsule. Cataract is the major cause of blindness in the both developing and developed countries. There are various causes for development of presenile cataract. Some of the risk factors are ocular trauma, environmental factors, like, prolonged exposure to sunlight, uncontrolled diabetes, nutritional deficiencies, cigarette smoking for prolonged periods, intake of certain drugs for prolong period, high myopia, etc.

Aims and Objectives: (1) To determine various types of presenile cataract. (2) To determine the common causes of presenile cataract.

Methods and Materials: Outdoor patients attending at the apex centre of north Bengal who are found to have presenile cataract and who gave consent to participate in the observational study, requested to fill the questionnaire and undergo a complete ocular examinations. The type of cataract and any cause of the cataract formation identified from the questionnaire, examination or investigations done are documented analysed using frequency distribution.

Results: 100 eyes of 59 patients were included in the study. The most common type of cataract was found to be posterior sub capsular cataract. The common causes identified were prolonged sunlight exposure, use of corticosteroids for prolong bleed period, chronic uveitis, smoking, etc.

Conclusion: Protection from sunlight exposure, adequate control of diabetes, avoidance of use of steroids, avoidance of cigarette smoking, proper management of uveitis help to prevent development of presenile cataract.

Keywords: Presenile, Cataract.
\end{abstract}

\section{Introduction}

Presenile cataract is degenerative change in crystalline lens. The commonest cause of blindness in the world is due to cataract. Cataract is the curable cause of blindness included in the vision 2020. It is a global initiative taken by WHO to combat preventable, curable and avoidable blindness. Around 7.75 million people were affected with cataract in the year 2001 and it is expected to go to about 8.25 million by the year 2020 due to a substantial increase in population above 50 years in India. In the year 2013, 6.105 million people were operated for cataract in India and it is expected to rise to 7.63 million by the year 2020 .

Different types of cataract formation are caused by different risk factors. Lack of a realistic casual model in cataract formation increases the difficulty of identifying the risk factors which 
causes cataract formation, although several epidemiological studies have been done to establish different factors as causative risks for both age related and presenile cataract. With the recent increase in presenile cataract, the currently existing burden of age related cataract is most likely to increase in the near future.

The exact reason for such occurrences of cataract, both age related and presenile are yet to be analysed. This study is an observational study done to identify the risk factors attributable to the onset of presenile cataract among the population of Subhimalayn Area of West Bengal, INDIA and its varying types.

\section{Methods}

The patients attending the outdoor clinics of the Department of Ophthalmology of the tertiary hospital, North Bengal Medical College \& Hospital (NBMC\&H) who were found to have pre senile cataract and who gave consent to participate in the observational study were included for the study and those patients having congenital or developmental cataracts were excluded from the study. All selected patients were requested to fill up a questionnaire consisting of their age, occupation, amount of exposure to sunlight per day, any personal habitual addictions to tobacco, smoking and alcohol, dietary pattern, history of any systemic diseases like diabetes mellitus, hypertension, tuberculosis, skin diseases, asthma, any history of ocular trauma or surgery, or use of any long term topical preparations and a detailed family history with any history of intraocular surgery performed for the patients or their relatives. Following this weight and height are recorded to calculate the body mass index [BMI] and then a complete ocular examination is done to look for any evidence of intra ocular inflammation which predispose the individual to cataract formation like chronic uveitis, and the type of cataract is categorized as immature, mature, hypermature, posterior subcapsular cataract or any specific cataract based on the morphological appearance of the lenticular opacity.

\section{Statistics and Result Analysis}

The analysis was done using frequency distributions. The results are as follows

\section{Table 1}

\begin{tabular}{|c|c|c|}
\hline $\begin{array}{c}\text { Outdoor } \\
\text { Activity }\end{array}$ & $\begin{array}{c}\text { Numbers } \\
(\mathbf{n = 5 9 )}\end{array}$ & $\begin{array}{c}\text { Percentage } \\
(\boldsymbol{\%})\end{array}$ \\
\hline$<4 \mathrm{hrs}$ & 10 & $16.95 \%$ \\
\hline$>4 \mathrm{hrs}$ & 30 & $50.85 \%$ \\
\hline Nil & 19 & $32.20 \%$ \\
\hline Diabetes & $\begin{array}{c}\text { Numbers } \\
(\mathbf{n = 5 9 )}\end{array}$ & $\begin{array}{c}\text { Percentage } \\
(\boldsymbol{\%})\end{array}$ \\
\hline$<5$ years & 6 & $10.17 \%$ \\
\hline$>5$ years & 7 & $11.86 \%$ \\
\hline Nil & 46 & $77.96 \%$ \\
\hline Hypertension & $\begin{array}{c}\text { Numbers } \\
(\mathbf{n = 5 9 )}\end{array}$ & $\begin{array}{c}\text { Percentage } \\
(\boldsymbol{\%})\end{array}$ \\
\hline$<5$ years & 6 & $10.17 \%$ \\
\hline$>5$ years & 6 & $10.17 \%$ \\
\hline Nil & 47 & $79.66 \%$ \\
\hline Skin Disease & Numbers & Percentage \\
& $(\mathbf{n = 5 9 )}$ & $5.08 \%$ \\
\hline Yes & 3 & $94.92 \%$ \\
\hline No & 56 &
\end{tabular}

From the above table 1, it shows that out of 59 cases, $50.85 \%$ people are stays more than 4 hours outdoor activities and people are generally doesn't have Diabetes, Hypertension and Skin diseases.

\section{Table 2}

\begin{tabular}{|c|c|c|}
\hline Refractive Error & $\begin{array}{c}\text { Numbers } \\
(n=59)\end{array}$ & $\begin{array}{c}\text { Percentage } \\
(\%)\end{array}$ \\
\hline Short Sightedness & 1 & $1.69 \%$ \\
\hline Long Sightedness & 1 & $1.69 \%$ \\
\hline Nil & 57 & $96.61 \%$ \\
\hline Uveitis & $\begin{array}{c}\text { Numbers } \\
(n=59)\end{array}$ & $\begin{array}{c}\text { Percentage } \\
(\%)\end{array}$ \\
\hline$>6$ months & 6 & $10.17 \%$ \\
\hline$<6$ months & 4 & $6.68 \%$ \\
\hline Nil & 49 & $83.05 \%$ \\
\hline Alcoholism & $\begin{array}{c}\text { Numbers } \\
(n=59)\end{array}$ & $\begin{array}{c}\text { Percentage } \\
(\%)\end{array}$ \\
\hline$>5$ Years & 8 & $13.56 \%$ \\
\hline Nil & 51 & $86.44 \%$ \\
\hline $\begin{array}{c}\text { Tobacco packs per } \\
\text { Year }\end{array}$ & $\begin{array}{c}\text { Numbers } \\
(n=59)\end{array}$ & $\begin{array}{c}\text { Percentage } \\
(\%)\end{array}$ \\
\hline$>5$ packs per year & 6 & $10.17 \%$ \\
\hline Nil & 53 & $89.83 \%$ \\
\hline Asthma & $\begin{array}{c}\text { Numbers } \\
(\mathbf{n}=59)\end{array}$ & $\begin{array}{c}\text { Percentage } \\
(\%)\end{array}$ \\
\hline Yes & 9 & $15.25 \%$ \\
\hline No & 50 & $84.75 \%$ \\
\hline $\begin{array}{c}\text { Consanguinity in } \\
\text { Parents }\end{array}$ & $\begin{array}{c}\text { Numbers } \\
(\mathbf{n}=59)\end{array}$ & $\begin{array}{c}\text { Percentage } \\
(\%)\end{array}$ \\
\hline 3rd Degree & 3 & $5.08 \%$ \\
\hline Nil & 56 & $94.92 \%$ \\
\hline
\end{tabular}


One pack year of smoking is defined as smoking one packet of cigarette daily for one year.

Table 3

\begin{tabular}{|c|c|c|}
\hline Occular Trauma & $\begin{array}{c}\text { Numbers } \\
(\mathbf{n = 5 9 )}\end{array}$ & $\begin{array}{c}\text { Percentage } \\
(\boldsymbol{\%})\end{array}$ \\
\hline Blunt & 1 & $1.69 \%$ \\
\hline Penetrating & 2 & $3.39 \%$ \\
\hline Nil & 56 & $94.92 \%$ \\
\hline $\begin{array}{c}\text { Topical Steroid } \\
\text { Use }\end{array}$ & $\begin{array}{c}\text { Numbers } \\
(\mathbf{n = 5 9 )}\end{array}$ & $\begin{array}{c}\text { Percentage } \\
(\boldsymbol{\%})\end{array}$ \\
\hline$>$ 6 months & 3 & $5.08 \%$ \\
\hline Nil & 56 & $94.92 \%$ \\
\hline $\begin{array}{c}\text { Systemic Steriod } \\
\text { Use }\end{array}$ & $\begin{array}{c}\text { Numbers } \\
(\mathbf{n = 5 9 )}\end{array}$ & $\begin{array}{c}\text { Percentage } \\
(\boldsymbol{\%})\end{array}$ \\
\hline$>$ months & 10 & $16.95 \%$ \\
\hline Nil & 49 & $83.05 \%$ \\
\hline STD & $\begin{array}{c}\text { Numbers } \\
(\mathbf{n = 5 9 )}\end{array}$ & $\begin{array}{c}\text { Percentage } \\
(\boldsymbol{\%})\end{array}$ \\
\hline Yes & 1 & $1.69 \%$ \\
\hline No & 58 & $98.31 \%$ \\
\hline
\end{tabular}

Table 4

\begin{tabular}{|c|c|c|}
\hline Chemotherapy & $\begin{array}{c}\text { Numbers } \\
(\mathbf{n}=\mathbf{5 9})\end{array}$ & $\begin{array}{c}\text { Percentage } \\
(\%)\end{array}$ \\
\hline Yes & 1 & $1.69 \%$ \\
\hline No & 58 & $98.31 \%$ \\
\hline $\begin{array}{c}\text { Sign of Intra } \\
\text { occular Lesions }\end{array}$ & $\begin{array}{c}\text { Numbers } \\
(\mathbf{n}=59)\end{array}$ & $\begin{array}{c}\text { Percentage } \\
(\%)\end{array}$ \\
\hline Yes & 9 & $15.25 \%$ \\
\hline No & 50 & $84.75 \%$ \\
\hline $\begin{array}{l}\text { Laterality of } \\
\text { Cataract }\end{array}$ & $\begin{array}{c}\text { Numbers } \\
(\mathbf{n}=59)\end{array}$ & $\begin{array}{c}\text { Percentage } \\
(\%)\end{array}$ \\
\hline RE & 7 & $11.86 \%$ \\
\hline LE & 9 & $15.25 \%$ \\
\hline $\mathrm{BE}$ & 43 & $72.88 \%$ \\
\hline Type of Cataract & $\begin{array}{c}\text { Numbers } \\
(n=59)\end{array}$ & $\begin{array}{c}\text { Percentage } \\
(\%)\end{array}$ \\
\hline IMC & 20 & $33.90 \%$ \\
\hline $\mathrm{MC}$ & 5 & $8.47 \%$ \\
\hline HMC & 2 & $3.39 \%$ \\
\hline PSCC & 26 & $44.07 \%$ \\
\hline Others & 7 & $11.86 \%$ \\
\hline BMI & $\begin{array}{c}\begin{array}{c}\text { Numbers } \\
(n=59)\end{array} \\
\end{array}$ & $\begin{array}{c}\text { Percentage } \\
(\%)\end{array}$ \\
\hline$<18.5$ & 4 & $6.78 \%$ \\
\hline $18.5-24.9$ & 34 & $57.63 \%$ \\
\hline$>25$ & 21 & $35.59 \%$ \\
\hline
\end{tabular}

In this study out of 59 patients, 34 patients had normal body mass index, 4 of them underweight and 21 of the overweight. Majority of the patients who had presenile cataract were women working as tea garden workers $(23.73 \%)$, homemakers (16.94\%), labourers (13.55\%) and farmers $(8.47 \%)$. The Most frequent type of cataract observed was PSCC in 26 patients out of 5, IMC cataracts in 20 patients, total cataract (mature and hypermature) in 7 patients and non-specific types in 7 patients.
Amongst the many studies relating to the causes and risk factors for the onset of age related cataract, The Beaver Dam Study and The Blue Mountains Eye Study stand as landmarks in the history of ophthalmology.

The Beaver Dam Study in Wisconsin, United States, was a study conducted in 1988 on the prevalence and incidence of age related cataract to identify the causes of cataract. A follow up of the study was recently conducted in 2010, after 22 years, and resulted in the finding of tobacco smoking as a major factor to cataract formation.

The Blue Mountains Eye Study in Australia, a population based cohort study was conducted to identify the risk factors for age related cataract formation. The study was conducted based on dietary factors, smoking, alcohol consumption, medications and refractive errors of the individuals enrolled for the study for a 10 years period. According to the study, higher intakes of protein, vitamin A, niacin, thiamine and riboflavin were associated with reduced prevalence of nuclear cataract. Prevalence of Cortical cataract was reduced with intake of polyunsaturated fats. However, no nutrients were associated with PSCC. The important findings from the study are the association of cigarette smoking and dietary deficiencies in vitamins and proteins with the occurrence of cataract.

\section{Conclusion}

Our study shows that presenile cataract is one the rise in today's context due to changes in the lifestyle of the people ranging from his diet, habitual addictions, job related stress, environmental influences. General avoidance of direct exposure to sunlight by use of Sun blocking cap, umbrellas, sunglasses, regular screening for diabetes in high risk individuals and refraining from any use of tobacco and alcohol consumption can reduce the risk factor of cataract formation. Long term usage of topical or systemic steroids should be avoided and regular eye screening should be done for any ocular or systemic disorders. As said, prevention is always 
better than cure, having a regular balanced diet rich in antioxidants combined with regular exercise and healthy lifestyle can surely help us in avoiding presenile cataract and probably might play a role in delaying the onset of age related cataract as well.

\section{References}

1. Brilliant LB, Grasset NC, Pokhrel RP, Kolstad A, Lepkowski JM, Brilliant GE et al. Associations among cataract prevalence, sunlight hours, and altitude in the Himalayas. Am J Epidemiol1983; 118: 250-264.

2. Kaluzny JJ. Mean age of patients with senile and presenile cataract in clinical material from 1987-1992. Klin Oczna 1993;95:277-280.

3. Mitchell P, Smith W, Attebo K, Healey PR. Blue Eye Study. Prevalence of openangle glaucoma in Australia. PubMed 1996 Oct;103(10):1661-9.

4. Early Treatment Diabetic Retinopathy Study Research Group (1991) Grading diabetic retinopathy from stereoscopic color fundus photographs-an extension of the modified Airlie House classification. ETDRS report number 10. Ophthalmology 98: 786-806.

5. Balasubramanian D, Bansal AK, Basti S, Bhatt K S, Murthy J S, Rao C M. The Biology of cataract. The Hyderabad cataract research group. Indian $\mathbf{J}$ Ophtalmol 1993;41:153-71.

6. Rahman A, Yahya K, Shaikh A, Fasih U, Zuberi BF. Risk factors associated with Pre-senile Cataract. Pak J Med Sci 2011;27(1):145-148.

7. Raman R, Pal SS, Adams JS, Rani PK, Vaitheeswaran K, Sharma T. Prevalence and Risk Factors for Cataract in Diabetes. Sankara Nethralaya Diabetic Retinopathy Epidemiology And Molecular Genetics Study Report No 17. Invest Ophthalmol Vis Sci $2010 ; 51(12): 6253-6261$.
8. Singh D, Tangirala R, Bakthisaran R, Chintalagiri MR. Synergistic effects of metal ion and the pre-senile cataract causing G98R alphaA-crystallin: Selfaggregation propensities and chaperone activity. Mol Vis 2009;15:2050-2060.

9. Skalka HW, Prchal JT. Presenile cataract formation and decreased activity of galactosemia enzymes. Arch Ophthalmol 1980; 98:269-73.

10. Solberg Y, Rosner M, Belkin M. The association between cigarette smoking and ocular diseases. Surv Ophthalmol 1998; 42: 535-547. 